\title{
LIGHT WEIGHT SELF COMPACTING CONCRETE WITH LIGHT EXPANDED CLAY AGGREGATE (LECA)
}

\author{
Khaled M. Heiza ${ }^{(1)}$; Fatma M. Eid ${ }^{(2)}$; Taha Masoud ${ }^{(3)}$ \\ 1- Professor of Reinforced Concrete Structures and bridges, Faculty of Engineering, Menoufia University, \\ Egypt.
}

2- Lecturer, Civil Engineering Department, Faculty of Engineering, Menoufia University, Egypt.

3- Master student, Civil Engineering Department, Faculty of Engineering, Menoufia University, Egypt

Email khheiza@gmail.Com ${ }^{(1)}$ fatma elzahraa2002@yahoo.COM ${ }^{(2)}$ Engtaha1990@yahoo.Com $^{(3)}$

\begin{abstract}
:
Lightweight concretes have been successfully applied in the building constructions for decades because of their favourable material properties, especially their low specific weight in connection with a high strength, a high capacity of thermal insulation and a high durability. The development leading to light weight self compacting concrete(LWSCC) represents an important innovative step in the recent years. This concrete combines the favourable properties of a lightweight concrete with those of a self compacting concrete. Research work is aimed on development of (LWSCC) with the use of light aggregates "Light expand clay aggregate (LECA)". In this investigation, first by specific gravity factor method, Twenty different mixes design of (LWSCC) were cast and tested to find out the values of slump flow, G-ring, V-funnel and 28 day compressive strength. Based on the results obtained, the best mix design was selected for further investigation. For the selected mix we study the effect of changing the reinforcement ratio on reinforced two way slabs when the dimensions were kept constant.

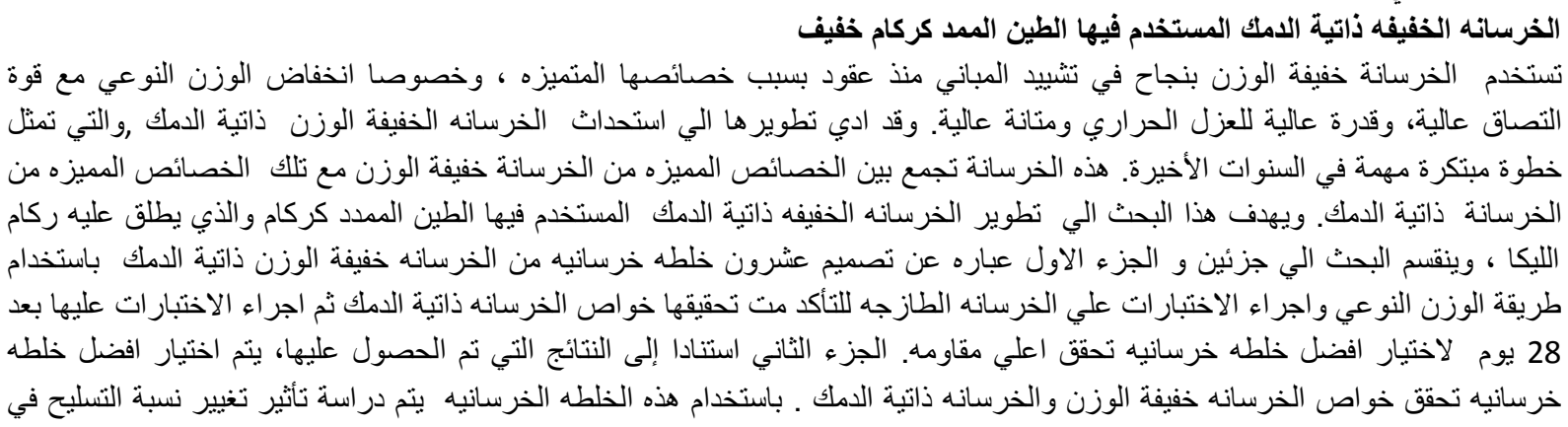

Keywords: LECA, light weight self-compacting concrete, Two way slabs.

\section{INTRODUCTION}

Lightweight self-compacting concrete (LWSCC) is expected to provide high workability without segregation and high durability with reduced weight. The success to production of high quality (LWSCC) lies in the use of aggregates. Expanded clay (LECA) is a ceramic material produced by expanding and vitrifying select clay in a rotary kiln. The use of expanded clay aggregate with other quality supplementary cementing materials (such as fly ash and silica fume) can provide highly workable and durable( LWSCCs). Expanded clay (LECA) and other light weight aggregates such as: expanded shale, pumice, slate, perlite, bottom ash etc. have been successfully used in the production of lightweight concretes (LWCs) over the decades [1,2,3]. Use of these aggregates has contributed to the sustainable development by conserving energy, maximizing structural efficiency and increasing the service life of structural lightweight concrete (LWC). These benefits add to those of (LWSCC) to further support sustainable development and contribute to projects becoming Leadership in Energy and Environmental Design (LEED) certified (ESCSI 2004)[4,5]. LWSCC is capable of filling up the formwork and encapsulate reinforcement by its self-weight without the need for additional compaction or external vibration. It has excellent segregation resistance, high flowability and passing ability at fresh state as well as better mechanical and durability properties in the hardened state $[6,7]$. 


\section{RESEARCH PROGRAM}

This research was conducted in two phases:1Phase (I )Focused on the experimental study of the fresh and hardened properties of LWSCC mixes. Six concrete mixtures were designed. Three key mix design parameters namely water (w) to binder (b) ratio $(\mathrm{w} / \mathrm{b})(0.28-0.35)$, dosage of high range water reducing admixtures (HRWRA) $(0.3-1.2 \%$ by total content of binder) and total binder content (B) (410$510 \mathrm{~kg} / \mathrm{m} 3$ ) were selected to study the influence on the properties of( LWSCC). The tested (LWSCC) properties were, slump flow, V-funnel flow time, Jring flow diameter/height difference, unit weight and compressive strength. Phase( II ) Based on the results obtained, the best mix which achieve the properties of light weight concrete and self compacting concrete so-called standard mix design was selected for further investigation. By the standard mix we study the effect of changing reinforcement ratio of two way slabs reinforced by welded wire mesh with variable diameter of wire.

\section{MATERIAL}

\subsection{Cement}

Portland cement type I (CEMI42.5N), provided by the Suze Cement Company., meeting the requirement of E.S. 7417/2001.

\subsection{LECA}

The coarse lightweight aggregate used in this study was locally produced from expanded clay type (LECA) from national cement company. The maximum nominal size of (LECA) was $15 \mathrm{~mm}$. The sieve analysis of( LECA) is given in Table (1). In this study, the dry (LECA) was pre-soaked in water for 48 hours before mixing in concrete until steady weight of LECA was achieved, to ensure that all voids inside (LECA) particles are fully filled with water. The physical and mechanical properties of coarse aggregate are given in Table (2).

Table (1 ): Sieve analysis of ( LECA):

\begin{tabular}{|c|c|c|c|c|c|}
\hline $\begin{array}{c}\text { Sieve size } \\
(\mathrm{mm})\end{array}$ & 19 & 16 & 9.5 & 4.75 & 2.36 \\
\hline$\%$ & 100 & 98 & 79 & 30 & 7 \\
\hline
\end{tabular}

Table (2 ): Physical and mechanical properties of (LECA) :

\begin{tabular}{|c|c|c|c|}
\hline Description & $\begin{array}{c}24 \text { h water } \\
\text { absorption: } \%\end{array}$ & $\begin{array}{c}\text { Specific } \\
\text { gravity }\end{array}$ & $\begin{array}{c}\text { unit } \\
\text { weight } \\
\mathrm{kg} / \mathrm{m} 3\end{array}$ \\
\hline LECA & 18.2 & 1.08 & 667 \\
\hline
\end{tabular}

\subsection{Fine aggregates}

Natural siliceous sand from El-khatatba was used as a fine aggregate.

\subsection{Fly ash}

Fly ash complies with chemical and physical requirements of American specification [ASTM C618], Europe specification [ EN450] .

\subsection{Silica fume}

Micro silica ( silica fume ) is by product resulting from industry of ferro silicon alloys . the product is a rich silicon dioxide powder where the average particles size is around 0.1 micrometers

\subsection{Viscosity Agent}

Sika viscocrete 3425 was used as viscosity enhancing agent (VEA). It contains a polycarboxylic -based copolymer-based mixture and modified cellulose product to achieve the dual action effect of high-range water reducer and viscosity-modifying admixture, respectively.it meets the requirements for super plasticizers according to swiss specification [ SIA 162(2989)], EUROPE specification [EN934-2], and American specification [ ASTM- C-494 type G and F ). Mechanical and physical properties are given in Table (3).

Table ( 3): Typical properties of viscocrete 3425 :

\begin{tabular}{|c|c|}
\hline Properties & Value \\
\hline Appearance & Clear liquid \\
\hline Density & $1.08 \mathrm{~kg} / \mathrm{Lit}$ (ASTM C494) \\
\hline PH Value & 4.0 \\
\hline Solid content & $40 \%$ by weight \\
\hline Chloride content & Zero \\
\hline
\end{tabular}

\subsection{Reinforcing steel}

Welded wire mesh is arranged in one layer with different diameters of wire in the slab

\section{Concrete mix design}

Twenty mixes of (LWSCC) were designed using the specific gravity factor method, as described elsewhere [8,9]. The best Six mixes showed in Table (4). The mix proportions of each mix were calculated by assuming that all its ingredients have to produce a cubic metre of concrete. Various mixes with different w/c ratio, All aggregate types used in this study were weighted on a saturated-surface-dry (SSD) basis, to achieve good moisture control in the concrete mixes. The constituent materials were mixed in a pan mixer with a capacity of $0.08 \mathrm{~m} 3$ and a mixing speed of $50 \mathrm{rev} / \mathrm{min}$ at ambient temperatures of about 25C. The (SCA) was separately added into the concrete after about $1 \mathrm{~min}$ of mixing. Mixing was continued for another $2 \mathrm{~min}$ before the mixture was left at rest for approximately 3 min. 
Table (4): Mixture design.

\begin{tabular}{|c|c|c|c|c|c|c|}
\hline Mix No. & $\mathbf{C}_{\mathbf{1}}$ & $\mathbf{C}_{\mathbf{2}}$ & $\mathbf{C}_{\mathbf{3}}$ & $\mathbf{C}_{\mathbf{4}}$ & $\mathbf{C}_{\mathbf{5}}$ & $\mathbf{C}_{\mathbf{6}}$ \\
\hline W/c & 0.35 & 0.32 & 0.32 & 0.3 & 0.3 & 0.28 \\
\hline \begin{tabular}{c} 
Binder(kg) \\
\hline $\begin{array}{c}\text { Cement } \\
(\mathrm{kg})\end{array}$
\end{tabular} & 510 & 410 & 500 & 510 & 500 & 510 \\
\hline FA (kg) & 76 & 62 & 72 & 76 & 72 & 76 \\
\hline $\begin{array}{c}\text { S F ( Kg) } \\
\text { Water (Lit) }\end{array}$ & 51 & 23 & 27 & 51 & 27 & 51 \\
\hline SP (Lit) & 3.8 & 1.2 & 6 & 5.1 & 1.5 & 3.8 \\
\hline Sand (kg) & 790 & 840 & 825 & 900 & 830 & 870 \\
\hline LECA (kg) & 390 & 474 & 412 & 450 & 415 & 410 \\
\hline
\end{tabular}

\subsection{Casting of Test Specimens}

a- Cubes with $10 \mathrm{~cm}$ side length were used for determination of the compressive strength of light weight self compacting concrete .

b- Three slabs casted using wooden mould with dimension $(1000 \mathrm{~mm} * 1000 \mathrm{~mm} * 50 \mathrm{~mm})$ as shown in figure(1).The thickness of the slabs were kept constant, The thickness of mesh layers and their combinations were varied in order to get higher strength. To prepare the mould for casting, it was first oiled which makes it easy for demoulding process. Initially, the first portion of mortar was evenly placed and the layer of mesh was then placed in position and mortar spacers were used in the areas between these meshes. Table (5) shows the properties of reinforced slabs.

Table (5): Properties of reinforced slabs.

\begin{tabular}{|c|c|c|c|}
\hline $\begin{array}{c}\text { Slab } \\
\text { No. }\end{array}$ & Dimension & Reinforcement & $\begin{array}{c}\text { Spacing } \\
\text { of mesh } \\
(\mathbf{c m})\end{array}$ \\
\hline $\mathbf{A}_{\mathbf{1}}$ & $100 * 100 * 5$ & $\begin{array}{c}\text { Welded mesh } \\
\text { thick } 3 \mathrm{~mm}\end{array}$ & $3 * 3$ \\
\hline $\mathbf{A}_{\mathbf{2}}$ & $100 * 100 * 5$ & $\begin{array}{c}\text { Welded mesh } \\
\text { thick } 4 \mathrm{~mm}\end{array}$ & $4 * 4$ \\
\hline $\mathbf{A}_{\mathbf{3}}$ & $100 * 100 * 5$ & $\begin{array}{c}\text { Welded mesh } \\
\text { thick } 5 \mathrm{~mm}\end{array}$ & $5 * 5$ \\
\hline
\end{tabular}

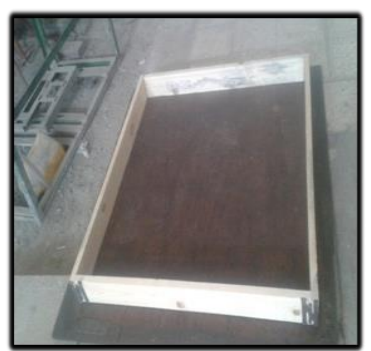

(A)

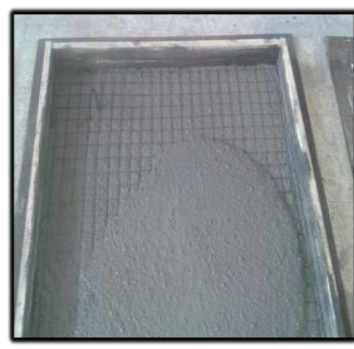

(C)

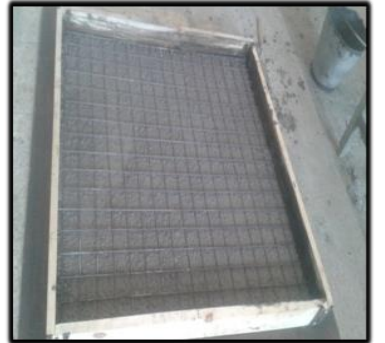

(B)

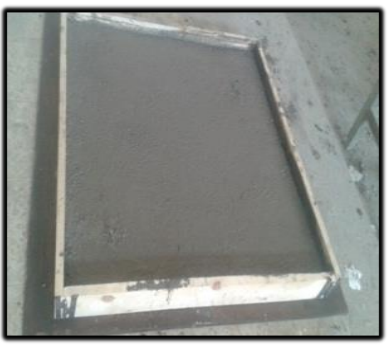

(D)
Figure (1): Casting of specimens

\section{RESULTS AND DISSCUSSION}

\subsection{Fresh characteristics of ( LWSCC)}

Immediately after the mixing, the value of slump flow, J-ring and V-funnel test were determine by the following methods Table (6).

Slump flow test

The slump flow test was used to evaluate the free deformability and flowability of (LWSCC) in the absence of obstruction..

The result of slump flow for mixtures showed that an increase in the w/b from (0.3 to 0.35$)$ significantly increased the slump flow However, at fixed( HRWRA\% )the slump flow range got limited with the increase of binder content.

Great positive effect of the coupled parameters (w/b and HRWRA) in increasing the slump flow. The slump flow test for (LWSCC ) is shown in Figure (2)

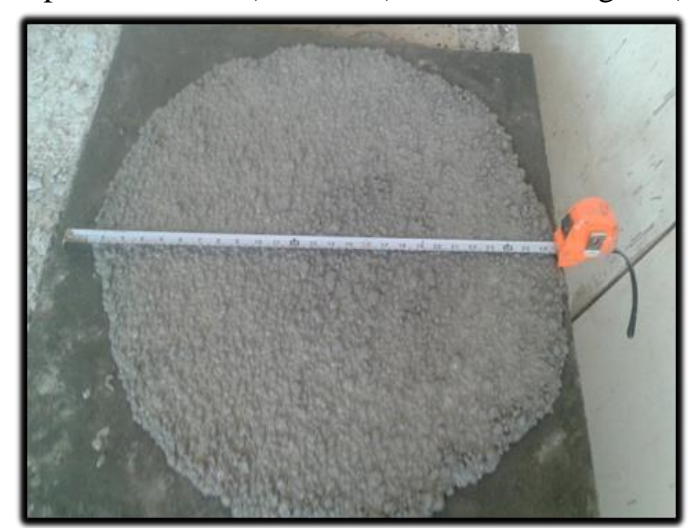

Figure ( 2 ) Slump flow test 


\section{J-ring test}

The J-ring test is used to determine the passing ability of the (LWSCC) (Figure 3).

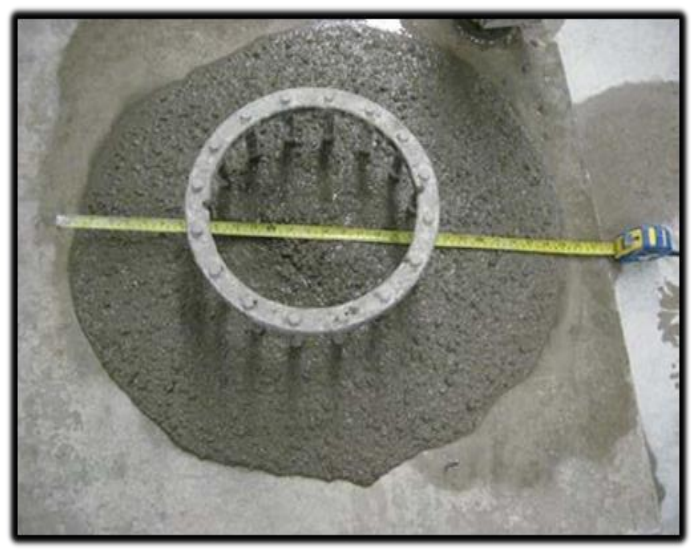

Figure (3 ): J-ring test

\section{V-funnel flow time test}

The V-funnel test is used to determine the deformability through restricted area .

An increase of the w/b from( 0.28 top 0.35 ) significantly reduced the $\mathrm{V}$-funnel flow time whereas an increase of (HRWRA) from 0.3 to $1.2 \%$ only slightly reduced the $\mathrm{V}$-funnel flow time. However, combined maximum increase of both (w/b and HRWRA) parameters resulted in a substantial reduction of the $\mathrm{V}$-funnel flow time The test was carried out for (LWSCC) as shown in Figure(4).

For all mixes, the slump flow and J-ring flow/J-ring height difference were positively influenced by (w/b and HRWRA). An increase of either or both parameters led to an increase in the measured responses/properties. However, an increase in the binder content alone affects the results negativelyshowing a decrease in the measured responses. so that mix NO C5 and C6 doesn't achieve values of acceptance of self compacting concrete [10].

Table (6): Fresh properties of mixtures

\begin{tabular}{|c|c|c|c|c|c|}
\hline $\begin{array}{c}\text { Mix } \\
\text { No }\end{array}$ & $\begin{array}{c}\text { Slump } \\
\text { flow } \\
(\mathbf{m m})\end{array}$ & $\begin{array}{c}\mathbf{T} \text { at } \\
\mathbf{5 0} \mathbf{~ c m} \\
(\mathbf{s e c})\end{array}$ & $\begin{array}{c}\text { V- } \\
\text { funnel } \\
(\mathbf{s e c})\end{array}$ & $\begin{array}{c}\mathbf{J}- \\
\mathbf{R i n g} \\
\mathbf{f l o w} \\
(\mathbf{m m})\end{array}$ & $\begin{array}{c}\mathbf{J}- \\
\text { Ring } \\
\text { height } \\
\text { diff } \\
(\mathbf{m m})\end{array}$ \\
\hline $\mathbf{C}_{\mathbf{1}}$ & 750 & 1 & 7 & 700 & 5 \\
\hline $\mathbf{C}_{\mathbf{2}}$ & 650 & 1.5 & 8 & 630 & 8 \\
\hline $\mathbf{C}_{\mathbf{3}}$ & 700 & 1 & 7 & 650 & 6 \\
\hline $\mathbf{C}_{\mathbf{4}}$ & 690 & 1.2 & 7 & 640 & 6 \\
\hline $\mathbf{C}_{\mathbf{5}}$ & 550 & 4 & 13 & 500 & 10 \\
\hline $\mathbf{C}_{\mathbf{6}}$ & 450 & - & 15 & 430 & 12 \\
\hline
\end{tabular}

\subsection{Hardened characteristics of ( LWSCC)}

As noted from the results shown in table (7) Compressive strength increase with decrease of w/c with saturated expanded clay and increased with increase of binder.

All mixtures unit weight less than $2000 \mathrm{~kg} / \mathrm{m} 3$ so that it can be light weight concrete.

The best mixture which achieve the requirements of light weight self-compacting concrete (LWSCC) with best strength is mixture no $\mathrm{C} 4$.

Table ( 7 ): Compressive strength and unit weight of different mixes:

\begin{tabular}{|c|c|c|c|c|}
\hline \multirow{2}{*}{$\begin{array}{c}\text { Mix } \\
\text { No }\end{array}$} & \multicolumn{2}{|c|}{$\begin{array}{c}\text { Compressive } \\
\text { strength } \\
\left(\mathbf{k g} / \mathbf{c m}^{\mathbf{2}}\right)\end{array}$} & \multicolumn{2}{c|}{$\begin{array}{c}\text { Unit weight } \\
\left(\mathbf{k g} / \mathbf{~ m}^{\mathbf{3}}\right)\end{array}$} \\
\cline { 2 - 5 } & $\mathbf{7 - d a y}$ & $\mathbf{2 8 - d a y}$ & fresh & air dry \\
\hline $\mathbf{C}_{\mathbf{1}}$ & 162 & 190 & 1820 & 1790 \\
\hline $\mathbf{C}_{\mathbf{2}}$ & 130 & 153 & 1850 & 1810 \\
\hline $\mathbf{C}_{\mathbf{3}}$ & 155 & 186 & 1880 & 1830 \\
\hline $\mathbf{C}_{\mathbf{4}}$ & 167 & 227 & 1910 & 1865 \\
\hline $\mathbf{C}_{\mathbf{5}}$ & 152 & 184 & 1860 & 1800 \\
\hline $\mathbf{C}_{\mathbf{6}}$ & 172 & 235 & 1900 & 1850 \\
\hline
\end{tabular}

\subsection{Behavior of reinforced light weight self- compacting concrete slabs.}

\subsubsection{Test Setup of slabs}

A special flexure loading frame was exclusively fabricated for testing the slabs and the details of the test setup is shown Fig. 5. In order to test the slabs on a four point loading (at 1/3rd span), over an effective span of $850 \mathrm{~mm}$, the center line of the slab, and the roller supports were marked and slab was seated on the bottom rollers . Loading was applied manually through a hydraulic jacking arrangement to cause downward deflection (see Fig.5). The load was given through the jack in small increments and the deflection of the slab was recorded up to failure using dial gauges. The proving ring readings and displacement values were observed simultaneously. The proving ring readings have been taken at every 5 division interval and the corresponding deformation values were observed in the displacement indicator. The loading was continued till the ultimate failure of the slab is reached, and the above measurements were taken at different load levels until final failure. The initial and final crack width was measured using a crack detection microscope. The ductility (deflection) of slabs using different reinforcing mesh thickness ( $3 \mathrm{~mm} ; 4 \mathrm{~mm}$ and $5 \mathrm{~mm}$ ) has been studied at first crack and ultimate failure loads. 

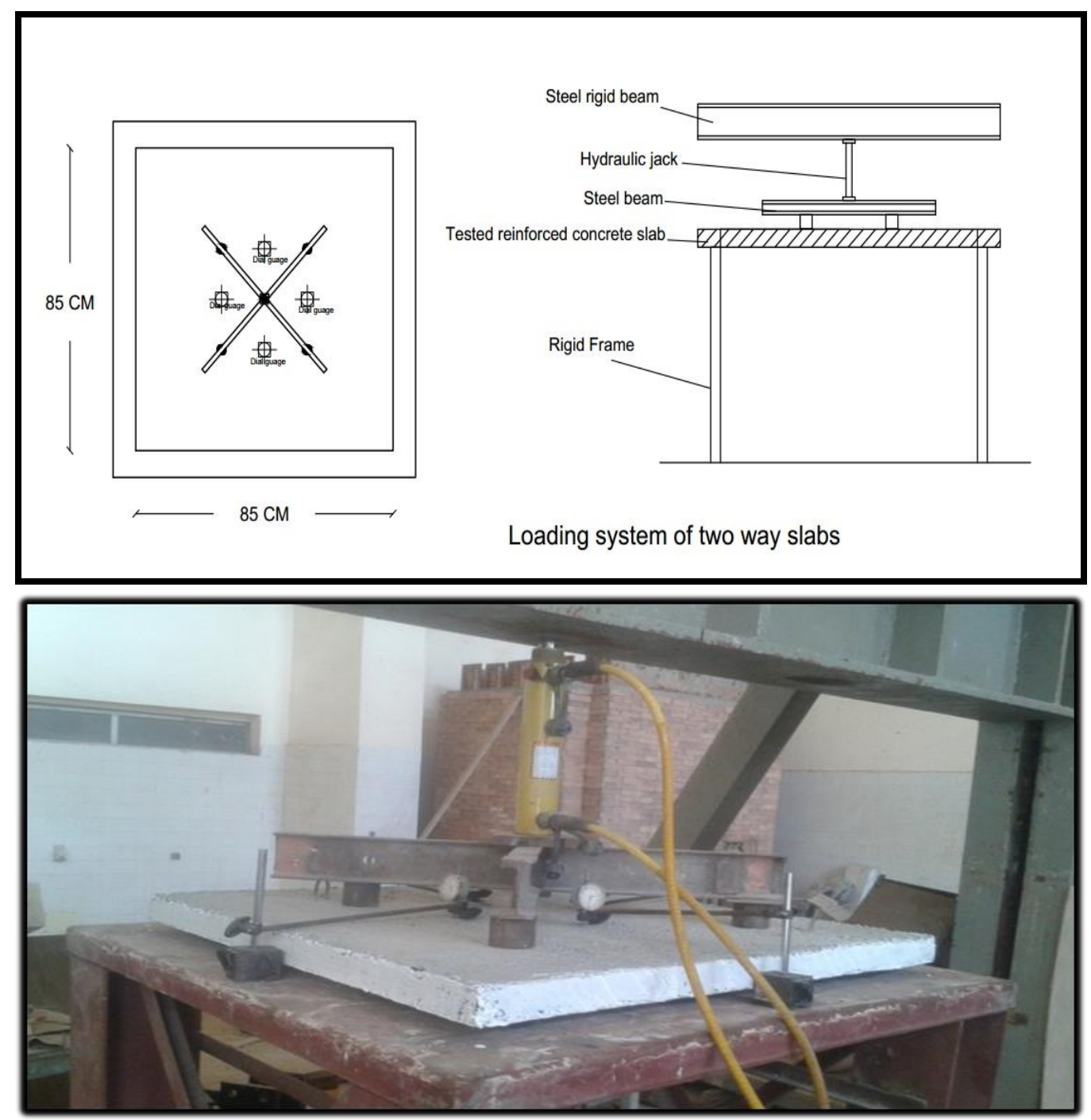

Figure ( 5 ) Test set-up

\subsubsection{Result}

A total of 3 specimens were tested in this investigation on four point loading tests and the results of the experimental tests carried out are analysed including the flexural loads and deflection (Fig.6,8,9.10). The failure of the slab specimen's results from the yielding of wire mesh reinforcement is followed by the crushing of mortar. Initially fine flexural cracks appeared at the bottom of the specimen. With further increase in the load, regularly spaced vertical cracks were observed and they extended from the bottom of the specimen towards top Fig.(7).The load was increased up to ultimate stage.

Slab No. (A3) reinforced with wire mesh $5 \mathrm{~mm}$ diameter recorded the highest value of ultimate load due to bigger diameter and pitch spacing ( $50 \mathrm{mmx}$ $50 \mathrm{~mm}$ ) while slab NO (A1) reinforced with wire mesh $3 \mathrm{~mm}$ diameter obtained the lowest value of ultimate load due to their smaller diameter and pitch spacing $(30 \mathrm{~mm} \times 30 \mathrm{~mm})$.

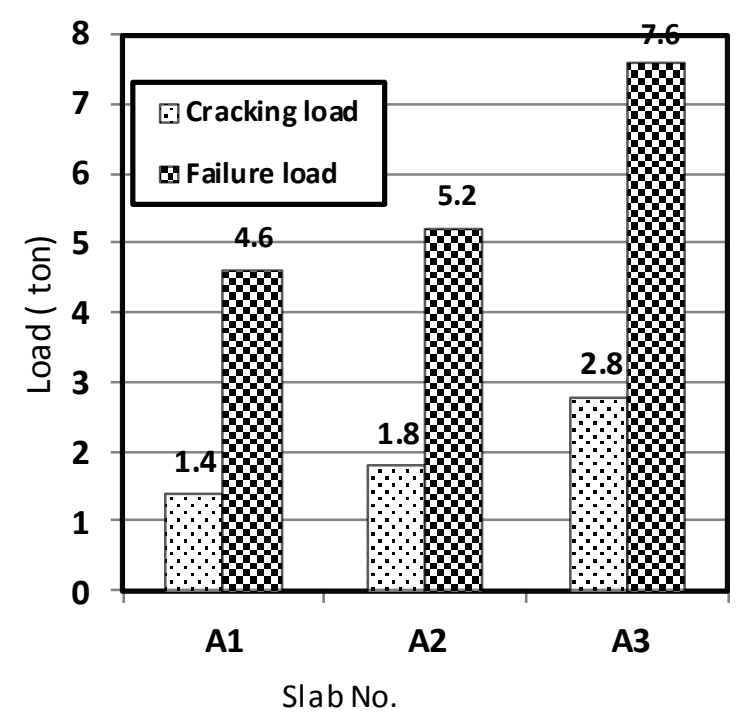

Figure ( 6 ): Cracking and failure load for testing slabs 
Khaled M. Heiza; Fatma M. Eid; Taha Masoud "LIGHT WEIGHT SELF COMPACTING CO..."

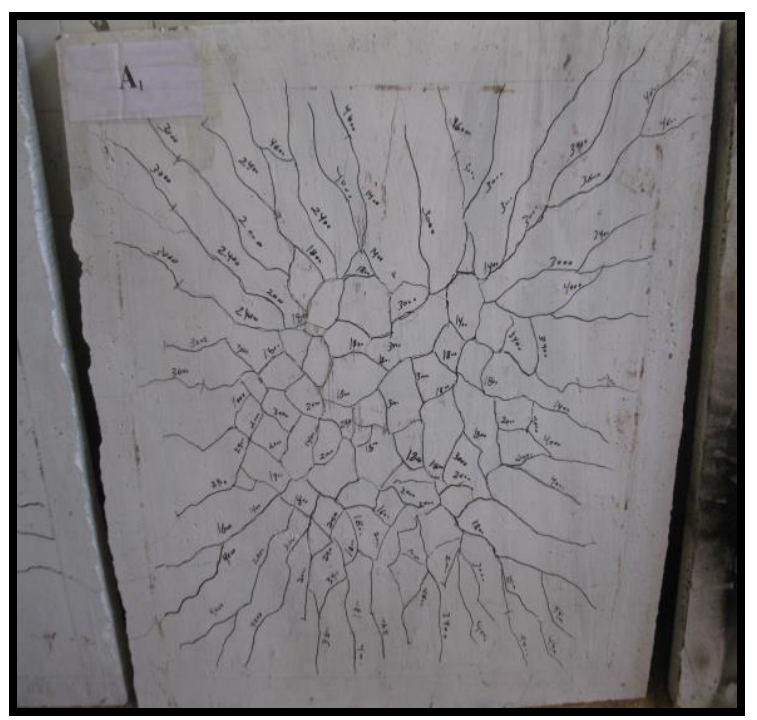

( A1 )

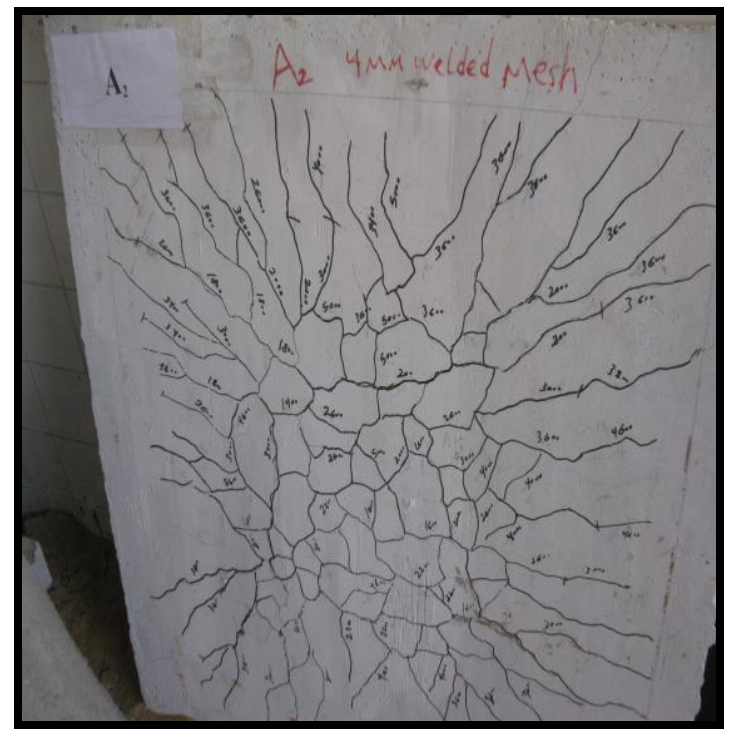

$\left(\mathbf{A}_{2}\right)$

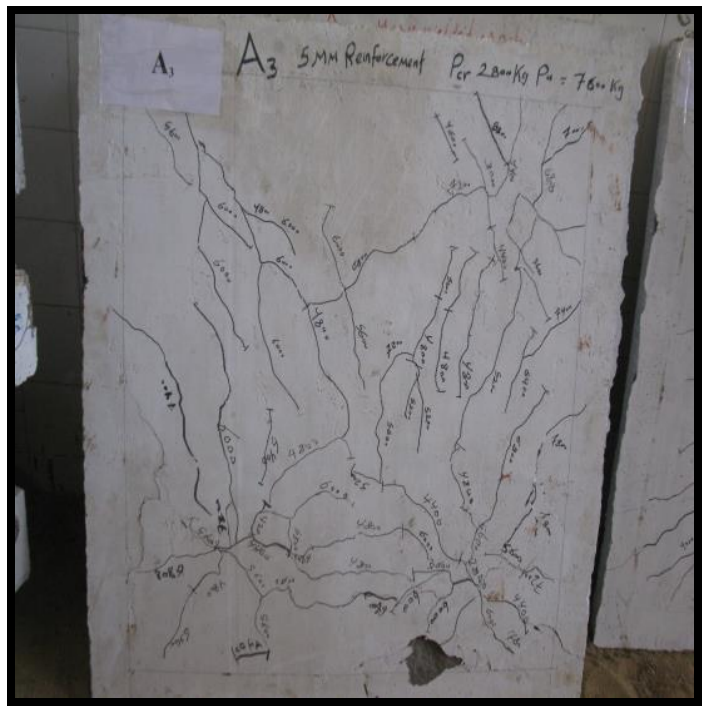

(A3)

Figure (7) : Crack pattern for slabs ( A1 , A2, A3)

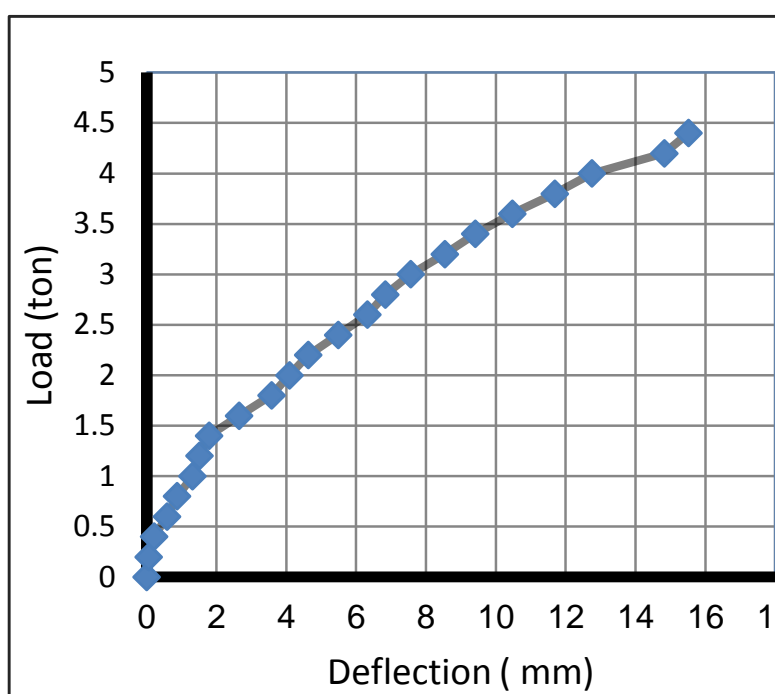

Figure ( 8 ): Load - deflection curve of slab ( A1 )

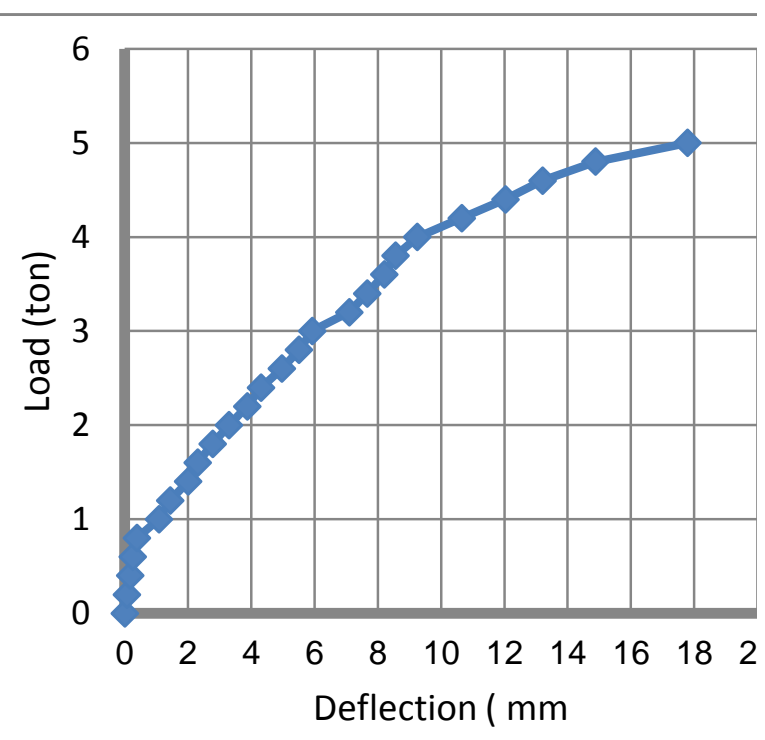

Figure ( 9 ): Load - deflection curve of slab ( A2)

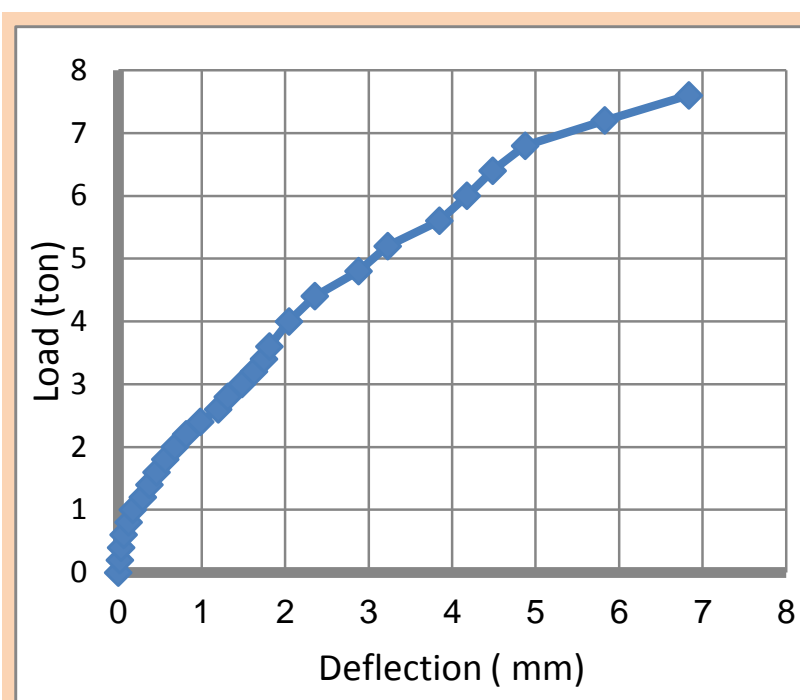

Figure ( 10 ): Load - deflection curve of slab ( A3) 


\section{Conclusions \\ Based on the results and observations of the experimental study presented, the following conclusions could be drawn as follows:}

1 - It is possible to manufacture a structural LWAC with low density and high self-consolidating characteristics (flowability, deformability, selfcompatibility and stability) using expanded clay aggregate.

2 - The way of mixing of this concrete is special: light-weight aggregate is recommended to be prewetted either in the mixing device by batching LWA and water (and adding the rest of materials after a while) or before the process of mixing (in the store or similar). Pre-wetted LWA gives higher stability of rheological behavior of fresh concrete and foaming of cement matrix is easier to control.

3 - The w/b has significant influence on the overall performance of (LWSCCs), including fresh and hardened properties. In terms of fresh properties, the $w / b$ has high influence on workability and HRWRA demand. The passing ability and filling capacity increase with the increases of w/b. The segregation resistance decreases with increase in w/b. (LWSCCs )with low w/b (0.3) required high dosage of (HRWRA) for flowability. In terms of hard properties the compressive strength increased with decrease of w/c , and increased with increase of binder amount .

4 - The flexural loads at first crack and ultimate loads depend on thickness of reinforcing mesh layers used in the slab.

5- The flexural loads of slab NO (A2), (A3) increased by $113 \%, 165 \%$ respectively compared to slab NO (A1).

6 - During testing it was observed that the slab did not break into pieces after failure, instead the cracks were found to widen. This is because the wire mesh holds together the cement mortar instead of breaking and falling off. By observing the cracks it was inferred that the slab with layer of wire mesh with $4 \mathrm{~mm}$ thickness has more crack pattern compared to slab with layer of wire mesh $5 \mathrm{~mm}$ thickness.. Hence with increase in thickness of layers of wire mesh we can increase the performance of slabs.
7.References

1 - Stamatakis, M. G., Bedelean, M., Gorea, H., Alfieris, D., Tziritis, E., \& Kavouri, S. (2011). Clay-rich rocks and mining wastes for the production of lightweight aggregates with thermal insulation properties. Refractories Worldforum, 3(1), 85-92

2 - Wu, Z., Zhang, Y., Zheng, J., \& Ding, Y. (2009). An experimental study on the workability of selfcompacting lightweight concrete. Construction and Building Materials, 23(5), 2087-2092.

3 - Hwang, C. L., \& Hung, M. F. (2005). Durability design and performance of self-consolidating lightweight concrete. Construction and Building Materials, 19(8), 619-626.

4- Hossain, K. M. A. (2004). Properties of volcanic pumice based cement and lightweight concrete. Cement and Concrete Research, 34(2), 283-291.

5- Fragoulis, D., Stamatakis, M. G., Chaniotakis, E., \& Columbus, G. (2004). Characterization of lightweight aggregates produced with clayey diatomite rocks originating from Greece. Materials Characterization, 53(2-4), 307-316.

6-Topc ,u, I. B., \& Uygunog lu, T. (2010). Effect of aggregate type on properties of hardened selfconsolidating lightweight concrete (SCLC). Construction and Building Materials, 24(7), 1286-1295.

7 - ESCSI. (2004). Expanded clay, shale and slate, a world of application (p. 5) Worldwide, Salt Lake City, UT, Publication No. 9349.

8- Bai Y, Ibrahim R and Muhammed Basheer PA (2004) Properties of lightweight concrete manufactured with fly ash, furnace bottom ash, and lytag. Proceedings of an International Workshop on Sustainable Development and Concrete Technology, Beijing, pp. 77-88.

9- Chia KS and Zhang MH (2004) Effect of chemical admixtures on rheological parameters and stability of fresh lightweight aggregate concrete. Magazine of Concrete Research 56(8): 465-47.

10 - ACI (American Concrete Institute) (1981) ACI 211.2-81 Standard Practice for Selecting Proportions of Structural Lightweight Concrete. ACI, Detroit.

11- EFNARC, (2005), "The European Guidelines for Self Compacting Concrete", Specification, Production and Use The Self-Compacting Concrete European Project Group, pp. 63 